\title{
Official and Vernacular Public History: Historical Anniversaries and Commemorations in Newcastle, NSW
}

\author{
ERIK EKLUND \\ Public History Review, vol 14, 2007, pp128-152
}

\begin{abstract}
$\mathrm{T}$ he city of Newcastle commemorated two bicentenaries within the space of seven years. In 1997 Newcastle celebrated the 1797 journey of Lieutenant John Shortland, who sailed north of Sydney in pursuit of escaped convicts, stopping at a river he called the Hunter. Shortland named and sketched the Hunter River and brought back samples of coal to Sydney. In 2004, however, the city marked another bicentennial, this time 200 years since the arrival of three ships under Lieutenant Charles Menzies on 30 March 1804. Menzies' task was to establish a penal outpost and place of secondary punishment for those mostly Irish convicts who had participated in the Castle Hill revolt in early March 1804. These anniversaries, and earlier ones such as Newcastle's centennial in 1897 and its sesquicentennial in 1947, were crucial moments of history making in the public sphere. History was evoked to celebrate progress, encourage civic loyalty and, more recently, to emphasise the city's transition into a post-industrial era.

In this article I explore the way in which commemorative dates in Newcastle's history were interpreted and utilised by public agencies such as the Newcastle City Council and presented to the general public. It will examine how history, heritage, politics and policy come together to use the past in a public way. Utilising a wellknown formulation by US historian John Bodnar, the clear shift in the themes and tenor of public history in Newcastle over this period has been from an 'official' to a more 'vernacular' style. ${ }^{1}$ Colonial and early to mid-twentieth century commemorations were characterised by an official program and official messages. History was mobilised as an element of community building with the themes and messages set by those with institutional power. Official public history emphasised unitary notions of progress while vernacular styles presented more diverse and occasionally more critical versions of public history. By 2004 commemorative events included more scope for active popular participation. Newcastle public history was nourished by community groups often with conflicting notions of public history, generating a
\end{abstract}


multivalent, multilayered sense of the past though, as we shall see, older themes persisted with remarkable durability.

Celebrations, commemorations and public festivals, usually with some kind of official or government approval, are central to the construction of public memory or a shared sense of identity. During these occasions, appropriate themes from the past and the present were abstracted and presented. The raw material of the past was selected often according to the needs of the present. Formal occasions, so organisers believe, required the distillation of complex historical experiences into one or two major elements usually with a 'feel good' theme. There is an extensive literature on imperial and national celebrations with case studies on events such as the Empire Day, the 1954 Royal Tour, the 1988 Bicentenary and the 2001 Federation celebrations. ${ }^{2}$ The myriad of regional and rural commemorations or even the particular inflexion of rural and regional celebrations on national occasions is not so well covered in Australia. ${ }^{3}$ This makes Bodnar's work all the more relevant since he includes important chapters on regional public history.

The history of Newcastle is an especially interesting case study. Australia's largest regional city has a distinctive and vibrant regional history. Its colonial history began not long after the white occupation of Sydney Cove. Subsequently, distinctive economic and social practices in the nineteenth and twentieth centuries have given the region some coherence. Being far enough away from Sydney, Newcastle forms a natural hub for practicing historians and relevant institutions, a feature which is emphasised by a strong sense of regional identity. The city also has a rich architectural inheritance of colonial and early twentieth century buildings, despite increasing redevelopment since the mid 1990s. For much of the twentieth century, however, the public history of the city was caught in the thrall of industrial modernity with all its forwarding-looking and teleological characteristics. History was most commonly evoked to measure progress and outline an optimistic industrial future. A central role for convicts also discouraged an extensive focus on Newcastle's early colonial history. Despite the commemorative orientation towards the present and future, interest in regional history began in earnest in the 1930s and remains a vigorous pursuit for numerous community groups and professionals.

In a city where 'history' had such an ambivalent position, large-scale historical commemorations make for intriguing analysis. While some scholars have pointed out that those watching or even participating in such major events may resist or undermine the principal themes, ${ }^{4}$ the messages portrayed on these significant occasions were undeniably powerful. In Newcastle these messages were not seriously criticised or questioned until the late twentieth century. This power was often sealed by the authority of a figurehead or political representative; a Governor, a Governor-General, a Prime Minister, a Mayor or local politicians were typically given some privileged platform to address a crowd, a moment of silence where the message was delivered in a sanctified and sanctioned fashion. Even when distinguished guests did not speak their presence gave proceedings an authority and moral weight. 
After reviewing the principal themes in the Newcastle commemorations of 1897 , 1947 and 1997, I then consider the 2004 'Newcastle 200' program. ${ }^{5}$ The 2004 commemoration not only marks the movement from official to vernacular history but also my own movement from analyst to participant. As an academic historian and a chair of a local working party with University, community and commercial participants, I become heavily involved in the 2004 commemorations. With the benefit of hindsight I am now able to reflect on this foray into the public sphere. In this sense the analysis offered here builds on both scholarly and experiential knowledge with my comments on the 1997 and 2004 commemorations being informed by personal observation and involvement. While the article concludes on a more personal note, my developing historical understanding of previous commemorations was, on reflection, a valuable context for my own involvement in 2004 indicating that scholarly and experiential knowledge can work together to deepen historical understanding. In the case of the 2004 commemorations, I argue that despite the problematic and occluded nature of historical representations embodied in commemorative festivals and events, my experience suggests that active involvement in this area may give historians at least some influence in the making of public history.

\section{The 1897 CentenNiAL}

Newcastle was the first area of white occupation in New South Wales (NSW) outside of the Sydney basin and was permanently established as a place of secondary punishment in 1804. Despite the official status of the names 'Hunter River' and 'Newcastle', other names such as 'Coal River' and 'Coal Harbour' were used interchangeably in both official and private correspondence. By 1819 there were almost 700 convicts in the area and by 1820 the total resident white population was approximately $1200 .^{6}$ The area was of major economic importance as a source of coal, timber, lime and salt for the new colony. Governor Macquarie's much-lauded program of public works, as well as extensive church and private building between 1810 and 1821, was underpinned by the products of the northern settlement. Yet the closure of the penal settlement at Newcastle in 1823 led to a decade or two of stasis. Population growth, trade and wealth flowed towards the lower Hunter Valley and the principal town of Maitland and its nearby port Morpeth. The population of Newcastle remained at, or close to, 1820 levels for the next twenty years. ${ }^{7}$

The absence of a single continuous thread of growth and development, plus the complexities surrounding the 'discovery' of Newcastle, meant that its history was not necessarily amenable to the principal themes of commemoration through the narratives of discovery, explorer and foundation. Yet, perhaps unsurprisingly, the 'facts' could be carefully selected and represented for any commemorative occasion. Official history was adept at coalescing national and regional historical accounts around a single powerful origin narrative.

Newcastle's centennial celebration, like many commemorative occasions of a similar nature, had a tentative historical basis. The occasion celebrated the naming and charting of the Hunter River by Lieutenant Shortland in September $1797 .^{8}$ That it 
was not the first landing in the area by Europeans was an inconvenient fact which official history conveniently ignored. William and Mary Bryant, along with six other escaped convicts and two children from Sydney, had landed in the area in March $1791 .^{9}$ There is some debate as to whether they entered what was later known as the Hunter River or halted at Glenrock Lagoon, five kilometres south of the Hunter River. The dramatic escape attempt of the Bryants is well known in Australian history. ${ }^{10}$ In Newcastle history, however, their claim to fame rests with their discovery and use of coal at Glenrock Lagoon. ${ }^{11}$

Another pre-1797 European contact came in June 1796. David Collins, JudgeAdvocate for the fledgling colony, detailed a visit by a party of fisherman 'from a bay near Port Stephens'. ${ }^{12}$ This party brought back samples of coal to Sydney. Unlike Shortland, a navy man with a subsequent heroic career, these unnamed fishermen of lowly status were difficult candidates to eulogize as European explorers, despite the impeccable European credentials of Collins as a source. Moreover, their visit to Coal River had been an occasion for violence between the visiting party and local Aborigines. Collins reported that the party 'conducted themselves improperly on shore, two of them were severely wounded by the natives' ${ }^{13}$ Collins does not record nor did he probably know of the outcome for local Aborigines. Coupled with these onshore visits by Europeans was Captain Cook's sighting in May 1770 of what became known as 'Nobbys Island'. ${ }^{14}$ Cook was the first European to sight the island at the entrance to the river even though he was unable to see the river mouth from his position at sea.

Details of these pre-Shortland European contacts came up in the 1897 Centennial Organising Committee meetings. One well-informed participant, H.J. Brown, a Newcastle solicitor, asked what exactly they were celebrating: 'If they were to celebrate their foundation they were some years too early as it was not for some years after that that the city was actually founded. ${ }^{, 15}$ Brown was right. Permanent settlement did not begin until 1804. The fishermen, however, were not appropriately heroic figures. The idea that fisherman visited the area in 1796 did not seem feasible according to J.J. Callaghan: 'If they did visit the place from whence did they come and to whom did they sell their fish?' This comment was reportedly meet with laughter. ${ }^{16}$

Shortland's journey north of Sydney in the Governor's whaleboat in September 1797 was a historically important moment in the eventual expansion of the newlyestablished penal colony beyond the Sydney Basin. He sketched the river, named it after Governor Hunter and returned a favourable report along with samples of coal to Sydney. In 1798 Shortland wrote to his father and described 'a very fine coal river' just south of Port Stephens which 'in a little time, will be a great acquisition to this settlement'. ${ }^{17}$ By the time of the 1897 centennial, however, Shortland's journey would be required to bear the burden of the moment of discovery and foundation of the city, two clearly inaccurate claims, even in Eurocentric terms. Thus 1797 became popularly invested with foundational meaning. From a date about European naming and charting of the Hunter River, 1797 was almost magically transformed to become 
a date about discovery and origin. The Newcastle Morning Herald wrote with some accuracy that Shortland can 'be assigned the credit of giving what is now the port of Newcastle a local habitation and a name'. Later in the same article, however, Shortland was praised in rather more elaborate prose: 'Shortland's name is forever connected with a discovery which will doubtless appear a much greater one when nearly one hundred years have expired since the young naval servant of King George III landed on the beach, and sketched Nobbys, the sandy flats now covered by wharves, and the bush-covered hills now studded with houses and the appliances of an advanced civilization. ${ }^{, 18}$

A cult of Shortland as the lone discoverer of Newcastle developed from the late nineteenth century and was dominant through to the 1980s. By 1918 Shortland's journey was simply tagged 'Discovery of Newcastle' ${ }^{, 19}$ and he became a key figure in subsequent commemorations including a re-enactment of his visit in 1922, the renaming of 'Sandgate Public School' to 'Shortland Public School' in $1932^{20}$ and major sesquicentennial celebrations in 1947. A re-enactment of Shortland's 1797 visit was the historical centre-piece of the sesquicentennial occasion. The federal electorate of 'Shortland', which is situated south of Newcastle and includes the suburbs edging Lake Macquarie, was created in 1949, while in 1957 the various Hunter-based Councils formed the 'Shortland County Council' as the region's major electricity utility. The power of the Shortland cult rests not so much on the historical basis of the claim of discovery but the widespread belief of what Shortland came to represent. Siobhan Lavelle argues that the contested site of the Marked Tree in the Blue Mountains, NSW, was 'a transmitter of symbolic meaning.' The Tree, apparently marked by explorers crossing the mountains in 1813, was a 'trigger' which activated ideas of colonial origin and discovery. ${ }^{21}$ In Newcastle it was not so much a place as a person in the form of Shortland who played this role.

If Shorthand's status as a British naval officer explains the preference for the 1797 date, the specific details of the 1897 celebration were shaped by more contemporary concerns. The most important model was the 1887 celebration of the fifty year 'record reign' of Queen Victoria. Queen Victoria's Golden Jubilee in 1887, and her subsequent Diamond Jubilee celebrations in 1897, were major events throughout the British Empire. Under Victoria's reign, dramatic public demonstrations of imperial patriotism and loyalty became stock-in-trade, a vital element of developing and maintaining an imperial consensus against a range of real and perceived threats. ${ }^{22}$ In Newcastle, the 1897 Organising Committee made constant references to the Golden Jubilee celebrations and to a lesser extent the 1888 centennial celebrations. The 1897 Jubilee celebrations included many of the same elements as the 1887 celebrations: fireworks, decorations including bunting and Chinese lanterns, a procession through the city and a day of sports.

Another immediate concern that was driving the efforts of the civic-minded Alderman and middle-class worthies of Newcastle was the knowledge that the Illawarra district had celebrated its centennial in fine style the previous year, in 1896. Located south of Sydney and increasingly centered on the growing commercial and 
service town of Wollongong, the Illawarra was seen in Newcastle as a major competitor for NSW government funding and private investment. Discussions about railway and harbour investment in the lllawarra in the 1890s had evinced critical comment from Newcastle members of parliament and the Newcastle Morning Herald. ${ }^{23}$ It was vitally important for civic pride and ongoing competition for regional investment that Newcastle mount a substantial and impressive celebration.

Pride in the town, region or nation could be developed through marking and celebrating progress since the first (acceptable) European contact - a vital element of official history. From the latter half of the nineteenth century, history was underpinned by themes of progress and improvement. The first commandant, the first settlers and then the first signs of 'civilisation' - the first post office, the first street lamp, and the first newspaper - became typical of such historical narratives, whether embodied in books or public celebrations. Overlaying the colonial drama of discovery and occupation came the proud trumpeting of economic progress. As Stuart Macintyre notes this history 'was measured in flocks and crops, bricks and mortar and then in the civilisation these made possible. ${ }^{24}$ Newcastle, in this regard, was no exception, and in the twentieth century the economic dimension to narratives of historical progress became more clearly dominant.

\section{The 1901 AND 1904 Centennials}

With Shortland and 1797 dominating the commemorative activities around the turn of the century, the $100^{\text {th }}$ anniversary of a 1801 settlement (later abandoned) and the subsequent $100^{\text {th }}$ anniversary of the 1804 permanent settlement of Newcastle were completely overlooked. In June 1801 Lieutenant Colonel William Paterson, together with Lieutenant Grant, Ensign Barrallier, a party of marines and a gang of convicts arrived at Coal River to work the coal and exploit the cedar, accessible via the Hunter River. ${ }^{25}$ The more senior and capable officers left in July 1801 leaving Corporal Wixstead in charge. The 1801 settlement struggled under the inexperienced leadership of Wixstead and later the overly severe Surgeon Mason and was withdrawn in early $1802 .^{26}$

The withdrawn 1801 outpost and 1804 reoccupation were not raised by local members in the NSW Parliament nor were they referred to by the Newcastle Morning Herald. The Federal Directory of Newcastle and District, published in 1901, contained key commemorative dates in the city's history. The Directory listed Shortland's 1797 journey of 'discovery' of the Hunter River from ' $16^{\text {th }}$ to the $18^{\text {th }}$ September', incorrectly since Hunter's eye sketch dates his discovery to the $9^{\text {th }}$ September ${ }^{27}$ The arrival of Menzies on 30 March 1804 along with the earlier failed 1801 convict settlement were conspicuous by their absence.

Anxiety over convict origins, common well into the twentieth century especially in areas of former convict outposts, probably silenced any commemorative impulse. ${ }^{28}$ In 1932 an influential Newcastle historian and founder of the Newcastle and District Historical Society, Wilfred James Goold noted the following when reviewing earlier historical work: 'There seemed to loom up the dark clouds of convictism and 
transportation. It had not been deemed wise to delve too deeply into the history for fear that some high person might have been found to be among the original convicts. ${ }^{29}$ In the 1880 s, an imposing fortification was constructed on Signal Hill above where the first coal mines were worked by convict labour. The area beneath the Fort, named Fort Scratchley from 1887, was found to be honeycombed with convict-dug tunnels and revealed evidence of convict artefacts such as leg irons. The Newcastle Morning Herald reported that such finds 'were too strongly suggestive of the horrors and tyrannies enacted in days gone... The underground dungeons and abodes of wretchedness then exposed are now, happily, for ever closed from human sight. ${ }^{30}$ The tunnels were covered over with the same determination of those such as the Chief Justice of Tasmania who argued for the systematic destruction of convict records to remove the stain of convictism. ${ }^{31}$

The pervading sense of embarrassment over Newcastle's convict origins was another important context for the preference for Shortland as the pioneering figure. Indeed, Shortland was not only a naval officer, he encountered the Hunter River whilst pursuing escaped convicts, who had audaciously seized the Cumberland, a boat which David Collins described as 'the largest and best in the colony belonging to the government'. ${ }^{32}$ As a discoverer he not only embodied the ideals of the British Navy and Empire. His actions in the service of that Empire also confirmed the marginalisation of the convicts in the colonising process. The unspoken question arising from this scenario was if the escaped convicts in the Cumberland had sailed past the river towards Port Stephens ahead of Shortland then surely they would have sighted the river mouth as well?

\section{Aboriginal History, Celebrations and Commemorations}

Awabakal and Worimi people live in and around the Hunter River. The traditional country of the Awakabal ranges from Lake Macquarie to the southern shore of the Hunter River. The Worimi live in what became known as the Stockton Bight/Port Stephens area, essentially north of the Hunter River though the dividing lines are not absolute. From the late 1790s initial contact between Aboriginal and non-Aboriginal people tended to be sporadic. But after 1804 the Awabakal and the Worimi had to contend with the permanent occupation of their country by convicts and their gaolers. Written, visual and archaeological evidence indicates that traditional patterns of their economy, society and kinship were maintained into the 1820s. Thereafter, traditional societies were overwhelmed by more widespread and intensive land use with many Aboriginal people choosing, or being forced, to relocate to a mission on Lake Macquarie which was established by Reverend Threlkeld in $1824 .^{33}$

This Aboriginal presence was ignored or marginalised in European narratives of the origins and growth of settler civilisation. In the 1897 celebrations, for example, a Newcastle Morning Herald editorial wrote that: 'A difficult storm-beaten place estuary has been improved to such an extent that very large steamers can moor at its wharves... All the needs of a civilized community, and nearly all the luxuries which can be desired can be procured here.' These were familiar terms in the late 
nineteenth century. Narratives of growth and progress were common. But even in these strongly Whiggish statements the indigenous presence was not far away for such writers. In this case, the editorial continued: 'A hundred years ago only a few wandering blacks maintained a precarious existence by hunting and fishing along the banks of the river. An aboriginal in our streets is now regarded as being strange to us, and almost less Australian than a Chinaman'. ${ }^{34}$ In a similar incident, of the 250 firemen who marched in the 1897 centennial procession, one brigade, the Central, featured 'a representation of an aboriginal's [sic] camp with a boy rigged up as a blackfellow to represent Newcastle of 100 years ago. ${ }^{35}$ Colonial celebrations had seen similar tableau. The 1888 centennial procession at Parramatta included a representation of 'primitive' Aboriginals as visual shorthand for what this country was like before white occupation. ${ }^{36}$

Such examples highlight the way in which the elision of the indigenous presence was central to the construction of a European sense of belonging and history. In marking out the nature of historical change over the last one hundred years, representations of Aborigines in 1897 operated as signs of what used to be. As Tony Hughes-d'Aeth pointed out with regard to one of the more influential examples of national historical mythmaking, the 1888 Picturesque Atlas: 'Indigenous people served an important function in defining the modernity of the colonising population. ${ }^{37}$ The march of history moved in a direction away from what they were imputed or represented to be. This point has been widely made with regard to Australian historiography and is relevant for Newcastle. ${ }^{38}$ Official history in the late nineteenth century, somewhat paradoxically, had no place for indigenous people, but also used representations of them to measure the extent of the apparent progress. Historical re-enactments and commemorations often associated the Aboriginal presence as a kind of prehistory - the foil for subsequent celebrations which focused on progress and development.

\section{The Sesquicentennial Celebrations, 1947}

Such was the complete erasure of the Aboriginal presence by the twentieth century that there were few, if any, representations of Aboriginal people by the 1947 celebrations. These commemorations followed similar themes to those of 1897 but were substantially larger and economic themes were much stronger. By this time the form and content of official history was more clearly defined. The NSW sesquicentennial celebrations in 1938 provided the main elements including largescale pageants, processions and re-enactments with a focus on heroic individuals of the British Empire and a dearth of material on convicts, all overlaid by a pioneer narrative. ${ }^{39}$ Some 100,000 people reportedly attended Newcastle on Saturday night, 6 September 1947. The Newcastle Morning Herald reported that 'the crowds were the biggest in Newcastle's history. For three hours, the city and the seafront were a seething mass. ${ }^{40}$ Taking a strong cue from the NSW sesquicentennial was the penchant for re-enactment, the Newcastle version of the arrival of Governor Phillip in 1788, re-enacted as the centre-piece for Australia Day activities in January 1938, 
found substance in the figure of Shortland. His landing was re-enacted on the following Tuesday with 'Shortland and his men' landing at Horseshoe Beach near the entrance to Newcastle Harbour and marching to the Newcastle Post Office, then an important city focus as the site of the Anzac Memorial and much daily activity and business. This was the culmination of the twentieth-century cult of Shortland as discoverer. The re-enactment had become a moment with singular foundational meaning in the city's history, a regional variation of the national white foundation story. Large crowds for the $150^{\text {th }}$ anniversary celebrations were testament to the power of official history to apparently unite and speak to large numbers of Novocastrians. As Julian Thomas pointed out with regard to the NSW sesquicentenary, the large crowds should not be so quickly dismissed by historians eager to claim the lack of authenticity of official history. ${ }^{41}$ For all its marginalisations and exclusions, official history as epitomised in these various events, had strong support among the local population.

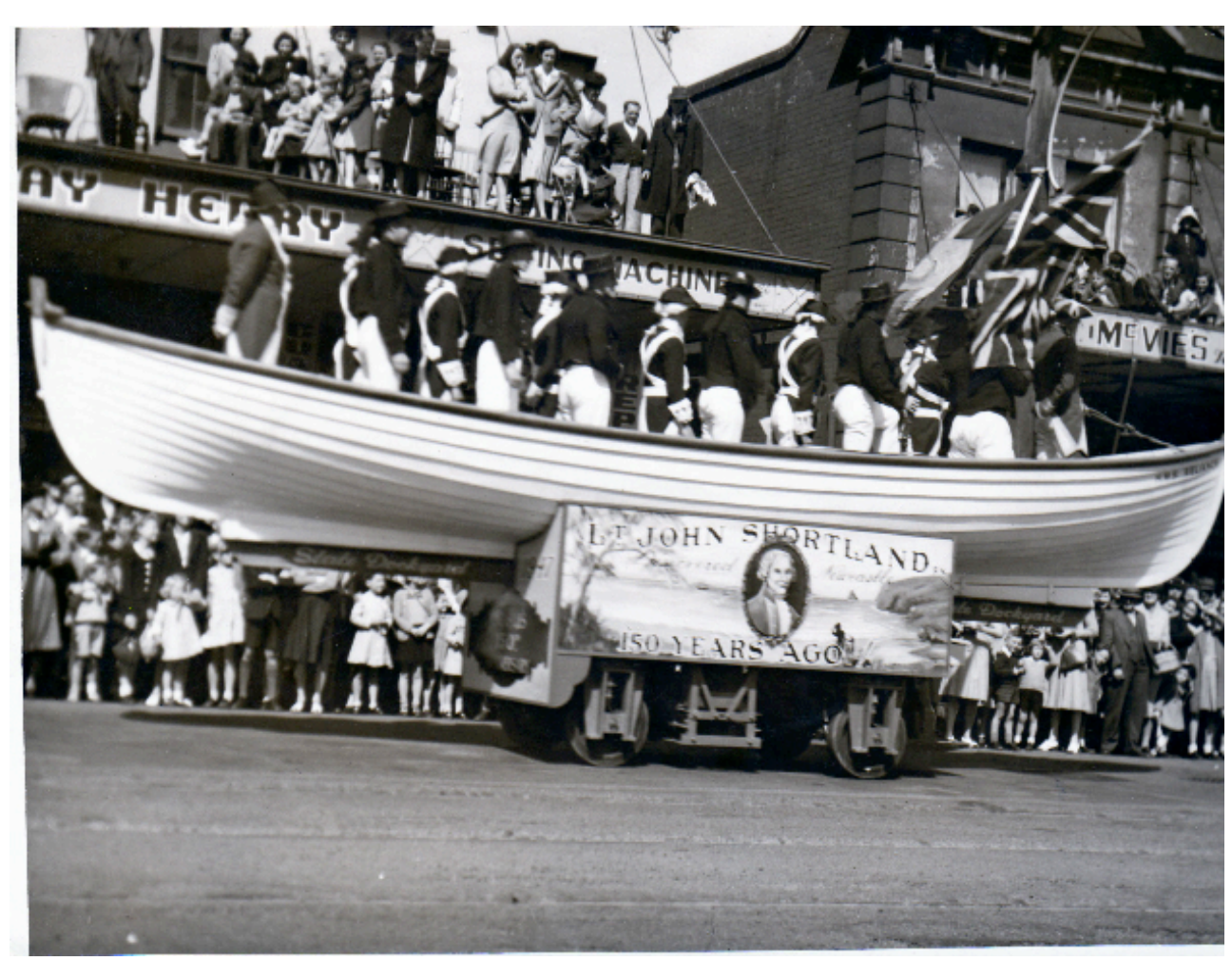

'Shortland and his men' process up Hunter Street, Newcastle during the 1947 Commemoration parade (Photograph from the Cynthia Hunter Collection)

Other $150^{\text {th }}$ celebration events included an Air Pageant, the State Eisteddfod, an Industrial Fair and an anniversary Mayoral Ball attended by many visiting dignitaries including Prime Minister Chifley. A few weeks later the Historical Society held their own ball where debutantes were presented to the guest of honor - the NSW Governor, Lt-General Sir John Northcott. ${ }^{42}$ The Newcastle City Council sponsored an 
expensive publication, Newcastle 150 years: 1797-1947, covering the progress of Newcastle since white settlement. ${ }^{43}$ Commemorative stamps issued for the $150^{\text {th }}$ anniversary showed a giant ladle pouring molten steel, and a coal wagon with a full load. ${ }^{44}$ The history content of such texts and representations were reduced and the more prominent theme became the industrial present and a potentially bright future. The commemorative impulse of the late nineteenth to record was edged aside by a new concern to publicise the region and its current industries.

The 1947 celebrations were less focused on history and more concerned with the present and the future, often using the products of earlier commemorations as major sources. The 1897 commemoration had included some forms of local history. Journalists John Windross and J.P. Ralston's published a narrative history of Newcastle in 1897 and local historian H.W.H. Huntington published an extensive history column in the Newcastle Morning Herald which ran from August 1897 to July 1898 providing detailed descriptions of the early European explorations of the Hunter River and the Hunter Valley. ${ }^{45}$ These texts were imbued with the notion of progress and change but still focused mainly on history. Huntington actually conducted a significant amount of research to compose his lengthy newspaper articles.

As with the 1897 celebrations, the immediate context shaped the specific character of the 1947 commemorations. In the post-war period it was widely believed that prosperity was to be found in Newcastle's industrial base, now of nationallysignificant proportions, and the region's place in a reinvigorated British Empire. 'Newcastle is the heart of basic industry in Australia', the 1947 Publication proclaimed: 'Its steel plants were the core of Australia's war effort in the dark years of 1939-45. Today, efficient and powerful, they are supporting the Empire as it moves into the post war period.' Overall, the 1947 publication is best summed up by the fact that it was produced by the 'Publicity Sub-committee of the Newcastle $150^{\text {th }}$ Anniversary Celebrations Committee'. This book was followed by a host of similar publications. The desire to publicise had replaced the desire to record.

\section{The 1988 BiCEnTENNIAL AND 1997 NeWCAStLe BicentenaRY}

From the late twentieth century historical commemorations were increasingly fraught with a number of concerns regarding the funding, content and cultural sensitivities of such events. A widespread diminution in the authority of official history, especially of the sort expressed in official parades and festivities coincided with the opening up of professional history to a number of dissenting or alternative points of view, and the growing recognition of many perspectives and positions on the past. Newcastle exemplified such developments. The presence of a more strongly vernacular style public history can be seen in the 1997 events but also dates back to the 1988 Bicentenary, though older forms of public culture did not easily subside in the face of more varied forms of historical representation.

Throughout the 1980s, especially with the 1988 Bicentennial, and into the 1990s with the High Court's Mabo judgment and ongoing Aboriginal activism, there was growing scholarly, public and political recognition of Aboriginal History. Official history 
was formerly characterised by such certainty about the value and centrality of the settler origin narrative. But as public discourse about Australia's past became somewhat more attuned to Aboriginal perspectives, many were asking: what of the Aboriginal perspective on these commemorations of white man's progress?

The first public sign in Newcastle of such dissent occurred during city's bicentennial celebrations in 1988. The celebrations were on the whole very well attended, with some 80,000 people crowding the newly restored Newcastle Foreshore on Australia Day. ${ }^{46}$ The Australian Bicentennial Travelling Exhibition arrived for a week-long-visit in September 1988 and set records for the most numbers of visitors on an opening day $(13,508)$ and best weekday $(13,277)$. Overall, 60,000 attended the Exhibition over five days. ${ }^{47}$ These were the familiar features of previous historical commemorations; large crowds, and public events with people as viewers rather than participants. Yet throughout January 1988 Aboriginal protestors maintained a presence on the 'Shortland Lawn' at the entrance to Newcastle harbour, a highly significant site since this is where the Shortland re-enactment was traditionally staged. These were the first clear fractures in the public culture of historical commemoration in Newcastle. These public expressions of dissent had been presaged by controversy that surrounded the Organising Committee in the lead up in the bicentenary. The Organising Committee was chaired by Labor Party councillor and professional historian from the University of Newcastle, Margaret Henry, who wished to bring a more critical, and in hindsight, what could be called a more vernacular style, to the city's commemorative efforts. Henry was an historian with a passion for social and women's history and was keenly aware of the challenges that Aboriginal history posed to mainstream Australian History. Her pioneering efforts were met with considerable resistance as vernacular history made its first tentative appearance while official history was still overwhelmingly dominant. ${ }^{48}$

Much like in 1897 and 1947, the 1988 celebrations in Newcastle also had an immediate context which shaped underlying themes. In this case the Newcastle economy was struggling with ongoing problems in the steel industry and job losses in the coal industry. In the period 1987 to 1988 nation-wide unemployment figures hovered around seven to eight per cent with higher rates in regional centres such as Newcastle. John Allen, Newcastle Bicentennial Co-ordinator, wrote that 'Newcastle will enter the Bicentenary with a depressed economic climate but a rising spirit.' Despite the economic difficulties and the 'grimy industrial city' image Allen indicated that a new image of a 'city with beautiful beaches and clean air, as well as culture, landscape and history' was emerging. ${ }^{49}$ This was the first sign that historical commemorations were looking to a new post-industrial future for Newcastle, a theme that would return in future celebrations. A major bicentennial project, the newly created Foreshore Park on reclaimed industrial land around the harbour epitomised this theme perfectly.

For the city's 1997 bicentennial commemorations the Newcastle City Council established its own Bicentennial Events Corporation (BEC), no doubt influenced by the Commonwealth Government's formation of a specific authority to manage the 
national bicentennial in 1988. The changing sensibilities with regard to white Australian narratives of origin were most clearly reflected in the decision of the BEC to dispense with the usual Shortland re-enactment. Given the centrality of the reenactment to previous celebrations and the status of Shortland in the minds of many Novocastrians as the heroic founding father, the decision naturally attracted controversy. The cult of Shortland still had adherents, so much so that members of the Stockton Historical Society staged their own re-enactment effectively transforming Shortland from an icon of official history to a protest symbol of the vernacular style. Shortland was still an influential figure locally, in particular for sections of the older Anglo-Celtic community who grew up with the full effects of the cult of Shortland. The BEC also developed a program of events that moved away from the street parades, pageants and balls of the sesquicentenary, focussing more on supporting visual arts, theatre and small community-based initiatives..$^{50}$ In part this attempt to emphasize the arts came in the context of economic change, deindustrialisation and a conscious attempt to re-imagine the city's identity especially in light of the planned closure of BHP's steel making operation, scheduled for $1999 .^{51}$ While the confident predictions of an industrial powerhouse may have seemed appropriate in 1947, by 1997 official history in Newcastle spoke to a new postindustrial future.

The 1997 commemoration also marked a modest return of history writing, with the Council commissioning a project which led to the publication of Riverchange. ${ }^{52}$ The edited collection included six contributions from professional and communitybased historians and was executed in line with the norms and standards of the history profession. Gone were the commemorative booklets designed to publicise the region. Riverchange included works around key themes in the city's history. The social history agenda is evident in the recognition of different perspectives on history and an attempt to not just celebrate progress and development but to understand patterns of historical change drawing out what we have lost and what we have achieved. The return of history in 1997 should not be overemphasised for the BEC was a reluctant supporter of Riverchange and publication was only guaranteed after additional funding from the then Premier of NSW, Bob Carr. The Riverchange publication, the reconciliation agenda and controversies surrounding the BEC leadership and budget added up to Newcastle's most introspective and perhaps most controversial commemoration to date.

\section{HISTORY AND 2004}

The nature of the 2004 celebrations was shaped by the 1997 experience. The Newcastle City Council appeared eager to avoid the controversies of 1997. Moreover, with the decline of the old-style commemorative structures it was as yet uncertain what form any historical commemorations should take and whether it would secure strong public support. In this context a modest program was a political imperative. 
Early in 2004, the Newcastle City Council's program of events for its bicentennial commemoration was released. Due to the Council's election cycle and the absence of an elected Council over the period covering 30 March, the Council chose to commemorate the occasion of permanent establishment of the convict settlement on 24 March, the day Lieutenant Menzies received his commission. This was instead of 30 March which was in fact the day that the three ships under Menzies arrived at 'Coal River' in 1804. On 24 March 2004 there was a book launch at the Newcastle City Art Gallery as well as a ceremonial reading of the commission given to Menzies. This choice of dates says a lot about the process of selecting elements of the past according to the needs of the present.

Despite a more modern inclusive sensibility, the affinities with the 1897 event were also strong. Like the 1897 correspondents who praised 100 years of progress, the Newcastle City Council 'Newcastle 200' program notes: 'On the 24th March 1804 Newcastle was a fledgling settlement facing an unforeseeable future. On the 24th March 2004 we need only to cast our eyes around the thriving Newcastle CBD, the bustling harbour and our region at large to understand how far we've come as a modern city. ${ }^{53}$ Apart from the fact that the settlement was not yet in existence on 24 March the similarities with the 1897 themes are striking with a central organising principle being the contrast between what we were and what we have become.

Reigniting another feature of the 1897 celebration the Newcastle Herald published a lengthy historical feature on the 1804 penal settlement by journalist Greg Ray. This marked a return to the tradition started by Huntington in 1897. The Council, however, was reluctant to fund another round of major publications, perhaps due to criticisms of financial excess from 1997. Instead, the Council commissioned a new short history of the city, Newcastle - a brief history, with the stipulation that no original research be completed. The final result of forty-eight pages was beautifully designed and illustrated but ultimately, given the constraints on the author and the small size of the publication, highly unsatisfying. There was no space to engage with the primary resources or develop a major new interpretation of the city's history. ${ }^{54}$

While the official elements of the 2004 program encouraged a renewal of the progress narrative of the late nineteenth century, the meaning of the 2004 Bicentennial was subjected to a greater level of debate and contestation typical of the vernacular style. Greens MLC Lee Rhiannon argued in the NSW parliament that this 'milestone was the perfect opportunity to look to the future and to think about what kind of city Newcastle is becoming.' Echoing the thoughts of at least some in the history and heritage community, she argued that 'many of the city's inhabitants want development that respects tradition and heritage. ${ }^{.55}$ Her comments came in the context of rapid housing and commercial development in Newcastle from the late 1990s as many older inner city areas or former industrial areas were redeveloped. And they highlight the way in which in a more vigorous political climate the meanings of commemorative dates can become contested.

During this period heritage and conservation issues in the heart of the city became major areas of public debate in light of development pressures as did 
attempts to revive the inner city through residential and commercial building. Many major projects were approved that some argued compromised the city's amenity and heritage fabric. ${ }^{56}$ The history and heritage community did secure an important result with the formal recognition of the area that witnessed the beginnings of the convict settlement and convict industry at Newcastle. Known as 'The Coal River Precinct', this area was formally listed on the NSW State Heritage Register on 19 December $2003 .^{57}$ In the last forty years the Newcastle foreshore in particular had been subject to many competing demands for its redevelopment or preservation. In the late 1960s in the face of public and institutional indifference towards Newcastle's colonial history, a major scheme to redevelop Newcastle's East End threatened many of these historic sites. ${ }^{58}$ Leading up to the 1988 Bicentenary, a plan inspired by Newcastle Lord Mayor Joy Cummings for the removal of waterfront industry and the revitalisation of the area ultimately secured open space in the immediate vicinity of the Coal River Precinct, reintroduced public access to the harbour front and activated the restoration of the Railway Sheds, the Station Master's Cottage, the Customs House, and the convict lumberyard.

The relative success of the 1988 Bicentennial was a clear message to local groups and individuals interested in heritage and sensitive redevelopment that commemorative dates were an excellent focus and rallying point. The approaching 2004 Bicentennial of Newcastle's permanent establishment in 1804 re-activated interest in recognising and protecting the Coal River precinct. The precinct incorporated sites and artefacts that have Aboriginal, convict, maritime, military and industrial significance and stretches from Nobbys Head and the convict-built breakwater through to Fort Scratchley and the harbour front area. It includes the sites from the original 1801 and 1804 settlements. This area was the birthplace of modern Newcastle, a place of first contact between the Aboriginal and European communities, and the site of crucial industrial, military, shipping and later, recreational activities. Local groups and individuals, in particular Doug Lithgow from the Parks and Playgrounds Movement Inc, and local historian, Cynthia Hunter, argued that it would be appropriate if the area was recognised and protected in time for the bicentennial celebrations. In the hands of those committed to conservation and heritage, the 2004 commemorations would be about working to secure the protection of historically significant areas. This was not a parade or a fair that celebrated progress; this was a call for the protection of the past in the face of rapid redevelopment. The increasing influence of vernacular history shifted the orientation of commemoration away from the twentieth century concern for the present and the future towards a deeper engagement with protecting and preserving the past.

A Working Party was set up hosted by the University of Newcastle. The Coal River Working Party (CRWP) was an unusual amalgam of university, community and commercial expertise. The group had been active in promoting, researching and protecting early colonial heritage since its formation in February 2003. A public meeting in April 2003 agreed to pass on the challenge of securing state heritage listing and an effective conservation management plan to the CRWP. ${ }^{59}$ (As noted 
earlier, 'The Coal River Precinct' was formally listed on the State Heritage Register in December 2003.)

By the end of 2003, however, it was clear that there was no planned official recognition of the re-establishment of the convict outpost on 30 March 1804 with Lieutenant Menzies in charge, a strange echo of the turn of the century disinterest in this possible commemorative date. A decision was made by the CRWP to organise our own Open Day at the Coal River Precinct, conducting tours around the vicinity for school groups and members of the community. The significant year was a natural focus of our lobbying as we argued that history and heritage deserved greater attention and resources in this bicentennial year. ${ }^{60}$

With the decision to run our own Open Day, I became a participant in the process of making public history. My position was as chair of the CRWP and one of the organisers of the planned day. By creating our own commemoration of sorts we were in danger of falling into the same trap as previous events. Celebrating 30 March could be seen as more 'Whiteman's History', simply reinforcing the idea of a foundational date. The date, however, was much more than this. It was also a moment where key elements of the history of Coal River came together - Aboriginal and non-Aboriginal, convict, industrial and maritime history. It was a moment of transition from the sporadic contact of the period 1788 to 1804 to more sustained engagement between the Awabakal and Worimi peoples and the British after $1804{ }^{61}$ The cultural sensitivities of the origin narrative should be acknowledged and indeed this issue that may have encouraged Newcastle Council to overlook the date. Nevertheless, 30 March can be seen as a shared moment in history, with meanings for both Aboriginal and non-Aboriginal Novocastrians. Despite being potentially problematic, this date made more sense historically than 26 March which was simply the date when Lieutenant Menzies received his commission. ${ }^{62}$

The strong focus of the CRWP's Open Day was on celebrating a diversity of histories. Walking tours of the convict coal mines recently located by the CRWP through documentary research and surveying work were the main theme. But the content and details of the day were left to numerous participants. Members of the public and groups of school children were invited to a site at the base of Fort Scratchley in Newcastle East where a hard-working band of volunteers erected a temporary marquee. From this central organising point _ very close to the site of the original 1801 and 1804 settlements and with a commanding view of Newcastle harbour, the breakwater and Nobbys Head _ groups were escorted along Fort Drive to view the coal mine locations. Traffic had been blocked allowing easy access for walkers and providing children a blank canvass for chalk drawings, with many stunning ships under sail, convict miners, and red coats gracing the area by the end of the day.

Aboriginal participants, both as Working Party members and as volunteer guides on the Day, offered their stories and perspectives in an event that was open-ended in its conception. For example, visitors were greeted by Shane Frost, from the Awarbukarl Cultural Resources Association, in the Awarbukarl language. Elsewhere 
on the walking tour visitors could talk to surveyors on how the coal mine locations were pinpointed, or to non-Aboriginal historians about the convict coal mines and the conditions the miners endured. The event was not so much planned as evolved. There were no dignitaries or speeches and very limited official recognition, so the Open Day fits into the realm of vernacular history, one of numerous informal, unofficial commemorations rather than officially sanctioned events.

As primary organiser of the Open Day I had applied for and received Council approval to be a nominated bicentennial event. Yet inexplicably our Open Day was left off the final published list of 2004 activities. In fact the 2004 program spawned a series of unofficial even dissenting 'events', further evidence of the fracture of official history as a tool for public legitimacy. In another case local historian Jack Delaney laid his own 'memorial' for the Irish convicts who were sent to Newcastle near the Wickham train station after unsuccessful attempts to secure support from the Newcastle City Council, and the Honeysuckle Development Corporation, a major player in the redevelopment of the harbourside area in Newcastle. ${ }^{63}$

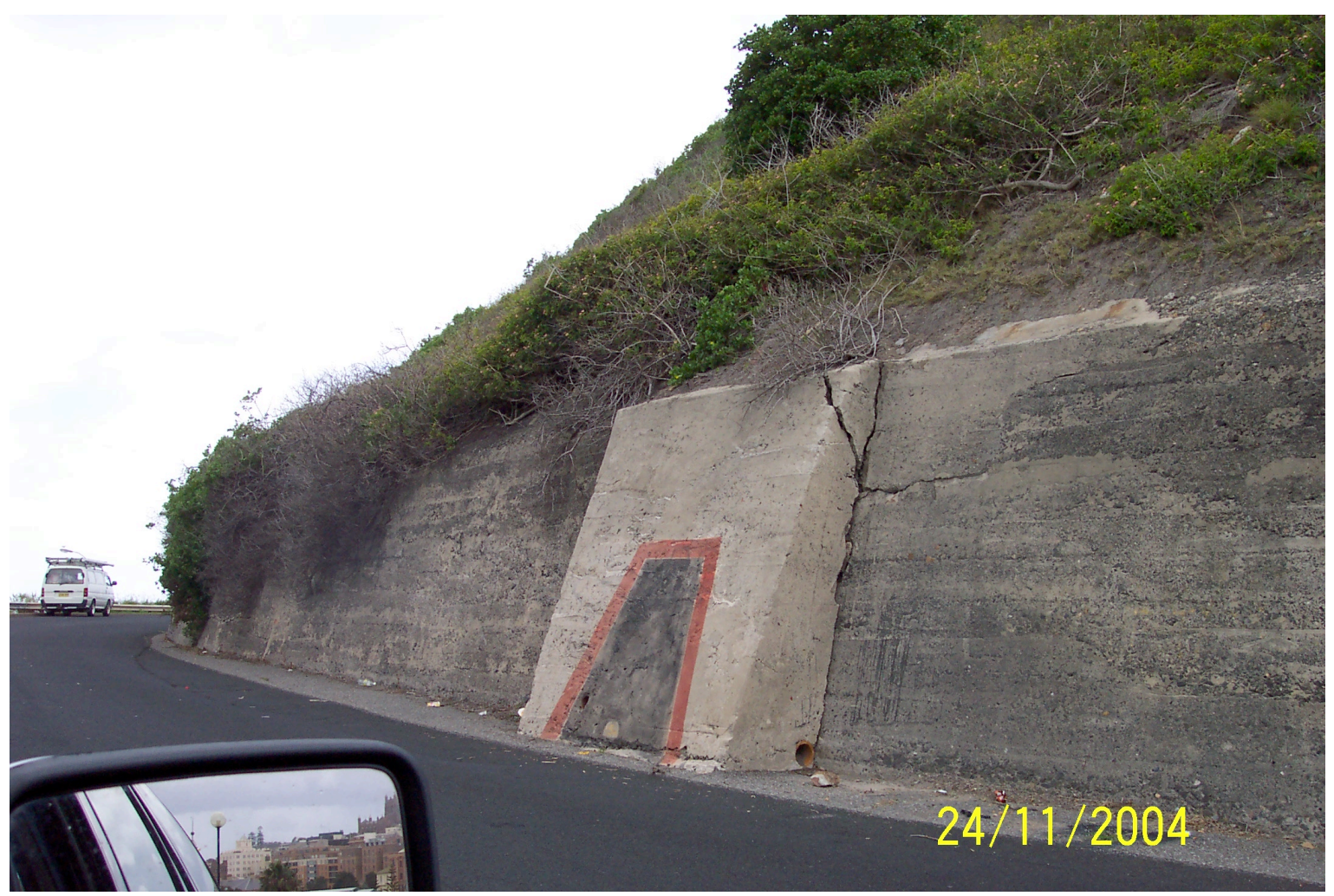

One of the three coal mine entrances located by the CRWP. It was around this area that walking tours were conducted. The entrance was painted using chalk to represent the original size of the adit (Photograph courtesy of Monteath \& Powys Pty Ltd)

The process of becoming a participant in an historical commemoration revealed the power of anniversaries and their obvious appeal for developing a public historical consciousness. With appropriate consultation and by creating an open-ended event 
where participants had some control over the format and content, the dangers of falling into colonial narratives of discovery, foundation and progress were minimized. Moreover, the unofficial nature of the event added to its informality and dissident quality. There were no visiting dignitaries, speeches or official moments where one particular interpretation of the event could be privileged and sanctified to a quiet passive audience. Instead, we had members of the public and school children moving around and through the site in what could only be called barely controlled chaos. Despite the advantages of a vernacular openness, the lack of official recognition and resources meant that our event was of a modest scale, reaching approximately 240 visitors including 120 school children.

\section{CONCLUSION}

One of the challenges for professional historians is to find effective and inclusive ways to disseminate our findings and build a greater appreciation of the past. In the case of the CRWP Open Day, the power of anniversaries was a crucial weapon, as it has been elsewhere, in the armoury of historians who want to engage in the public sphere. The shift from the parades and festivities of official history to more openended and potentially inclusive events of vernacular history allows historians some opportunity to intervene in the crucial process of making public history. Community participation, now a more clearly recognised component of commemorative activities, will not necessarily produce historical commemorations that are more historically defensible. But this movement does allow for more involvement by professional historians and greater space to use such occasions to create a more informed and inclusive public history of the vernacular style.

Many common themes across all of Newcastle's historical commemorations can be discerned. The past is selected, celebrated and simplified, and above all, used as a marker to chart progress and development in order to publicise a region or town. Yet by the end of the twentieth century the public culture of formal parades, speeches and re-enactments was in transition. The role of history as imparting a kind of sanctioned public legitimacy to the Australian state and social order was modified as the discipline opened up to more diverse forms of history making from the 1970s. In Newcastle the public culture of historical commemoration moved from a unified western notion of historical origin, discovery and progress towards to a more multilayered perspective. The first clear signs came in the 1988 Bicentennial and the growth of dissident or unofficial events continued in 1997 and 2004.

While the general trajectory of change was from official to vernacular public history, present days concerns also shaped the character and tone of commemorative events with Queen Victoria's reign, the British Empire, the economy, regional rivalries and changing political sensibilities all playing a role. It is also too simple to claim that vernacular styles simply replaced official history at Newcastle. Despite the changes and the diversity of approaches by the end of the twentieth century, there were still affinities between the 1897, 1947 and 2004 commemorations in the formal elements of official ritual and commemoration. The continuity of the 
progress narrative was modified from the 1980s and the concern to preserve and protect evinced by the CRWP and others joined the usual statements and messages about the extent of the city's transition and progress. Public history at Newcastle now reveals a more diverse series of themes and concerns despite official history and the organisations that control and mobilise it still being heavily interested in history as a way to build regional loyalty and emphasise possible futures according to presentday problems. For all its problems official history had an ability to speak to large groups of people. And it is hard to see public history thriving without some official recognition and support. A way forward may lie in some self-conscious blending of the two; an official program with spaces and opportunities for the vernacular to assert itself. Certainly, the boundaries between the two styles are not absolute. Even an icon like Shortland, once a central figure in official history, could pass over to the other side and become a symbol of a dissenting vernacular re-assertion of AngloCeltic origins.

Another commemorative date looms on the horizon. The Newcastle Borough Council was formed in 1859 and its successor organisation, Newcastle City Council, will celebrate its sesquicentenary in 2009. Expect a flood of commemorative projects and there may be further opportunities for those in the history community to contribute to Newcastle's public history.

\section{ENDNOTES}

\footnotetext{
1 John E. Bodnar, Remaking America: public memory, commemoration, and patriotism in the twentieth century, Princeton University Press, Princeton, 1992, p13. I would like to thank Cynthia Hunter, Doug Lithgow and the two anonymous referees for their valuable comments and suggestions.

${ }^{2}$ Ian Hoskins, 'It is inevitably a people's park: Ceremony and democratic sentiment at the opening of Centennial Park, 1888', Studies in Australian Garden History, vol 1, 2003, pp55-70; Martha Sear, 'Femininity that Calmed the Crowds: Lady Carrington at the Queen's Jubilee Celebrations Sydney 1887', Journal of Australian Studies, no 52, 1997, pp10-19; Richard White, 'National Days and the National Past in Australia', Australian Cultural History, no 22, 2003, pp55-72; Stewart Firth and Jeannette Hoorn, 'From Empire Day to Cracker Night', in P. Spearritt and D. Walker (eds), Australian Popular Culture, Sydney, Allen \& Unwin, 1979, pp17-38; Jane Connors, 'Betty Windsor and the Egg of Dukemberg: men, women and the monarchy in 1954', Journal of Australian Studies, no 47, 1996, pp67-80; and Stephen Alomes, 'Celebrations and Historical Memory: Federation and Beyond', Tasmanian Historical Studies, vol 8, no 1, 2002, pp25-41.

${ }^{3}$ For one example of a regional analysis of public history see Elizabeth Furniss, 'Timeline History and the Anzac Myth: Settler Narratives of Local History in a North Australian Town', Oceania, vol 71, no 4, June 2001, pp27997. See also Nancy Cushing, 'Living History: the city of Newcastle as a museum', Public History Review, vol 6-7, 1996, pp49-61.

${ }^{4}$ See, for example, Hoskins ('It is inevitably a people's park', p68) who notes that sections of the crowd during the opening of centennial park in 1888 pushing, shoving and jeering 'were collapsing the distinction between rules and ruled... forcing a place for itself in the proceedings within the context of spatial layout of the ceremonial proceedings.'

${ }^{5}$ Given space constraints and a concern to be succinct rather than comprehensive I have omitted other commemorative dates in Newcastle's history including the 1909 anniversary of fifty years of local government, and the local celebrations for the 1970 commemoration of James Cook's Endeavour voyage.

6 J.W. Turner, 'The Development of the Urban Pattern of Newcastle: A Critique', Australian Economic History Review, vol XI, no 2, September 1971, p179.

${ }^{7}$ Ralph Mansfield, Analytical View of the Census of New South Wales for the year 1841: with tables showing the progress of the population during the previous twenty years, Kemp \& Fairfax, Sydney, 1841, p27.

8 'J. Shortland, Jun., To J. Shortland, Sen. HMS Reliance, Sydney Cove, Port Jackson'. Lieutenant John Shortland of the H.M.S. Reliance officially 'discovered' the River on the 9 September 1797 while en route to Port Stephens. See Historical Records of NSW, vol. 3 pp481-82.
} 
${ }^{9}$ Victor Crittenden (ed), Memorandums: Escape from Botany Bay, 1791: being 'Memorandoms' by James Martin, Mulini Press, Canberra, c1991, pp2-3.

${ }^{10}$ C.H. Curry, The Transportation, Escape and Pardoning of Mary Bryant, Halstead Press, Sydney, 1983 and M. Walker, A Long Way Home: The Life and Adventures of the Convict Mary Bryant, Wiley, Chichester (UK), 2005.

${ }_{11}^{11}$ Martin, Memorandums, pp2-3.

${ }^{12}$ David Collins, An account of the English colony in NSW from its first settlement in January 1788 to August 1801 (2nd edition), T. Cadell and W. Davies, London, 1804, p328.

13 ibid.

${ }^{14}$ Cook's journal entry on the 10 May 1770 reads in part: 'A small round rock or Island laying close under the land bore $S^{\circ} 82^{\circ}$ West dist ${ }^{\dagger} 3$ or 4 Leagues', 'Cook's Endeavour Journal', Sea Souths: Voyaging and CrossCultural Encounters in the Pacific, National Library Australia/Centre for Cross Cultural Research, ANU, http://southseas.nla.gov.au/journals/cook/17700510.html (14 May 2007).

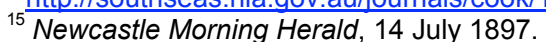

16 ibid.

${ }^{17}$ Lieutenant John Shortland of the H.M.S. Reliance named and charted the river on the 9th September 1797 whilst en route to Port Stephens. The letter to his father reporting the discovery is in Historical Records of NSW, vol 3 pp481-82. For biographical details on Shortland see Arthur McMartin, 'Shortland, John (17691810)', Australian Dictionary of Biography, vol 2, Melbourne University Press, Melbourne, 1967, pp443-444.

${ }^{18}$ Newcastle Morning Herald, Editorial 30 June 1897.

${ }_{19}^{19}$ Newcastle Morning Herald, 7 September 1918, 'Discovery of Newcastle (with copy of Shortland's map)'.

${ }^{20}$ Sandgate School, which opened in 1930, changed its name to Shortland Public School in 1932. (http://www.shortland-p.schools.nsw.edu.aul )(1 July 2006).

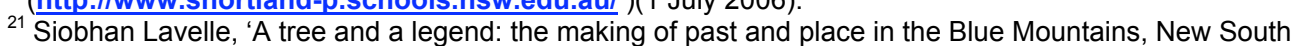
Wales', Journal of the Royal Australian Historical Society, vol 89, no 1, June 2003, p20.

${ }^{22}$ Dorothy Thompson, Queen Victoria: gender and power, Virago, London, 1990, pp132-36; John Mackenzie (ed), The Victorian Vision: Inventing New Britain, V\&A Publications, London, 2001; and Martha Sear, 'Femininity that Calmed the Crowds: Lady Carrington at the Queen's Jubilee Celebrations, Sydney 1887', Journal of Australian Studies, no 52, 1997, pp10-19.

${ }^{23}$ Henry Lee, 'The Development of a Coal Trade in the Wollongong District of New South Wales', PhD Thesis, University of Wollongong, 1992 and Erik Eklund, Steel Town: the making and breaking of Port Kembla, Melbourne University Press, Melbourne, 2002, pp138-39.

${ }^{24}$ Stuart Macintyre, 'The Writing of Australian History', in D. Borchardt and V. Crittenden. (eds), Australians: $A$ Guide to the Sources, Fairfax, Syme \& Weldon, Sydney, 1988, p9.

${ }^{25}$ Lieutenant Grant to Governor King, $14^{\text {th }}$ June 1801 in Historical Records of New South Wales, vol 4 Charles Potter, Sydney, 1896, pp404-09. See also Cushing, 'The Changing Meanings of Heritage' in C. Hunter (ed), Riverchange: Six New Histories of the Hunter, Newcastle Region Public Library, Newcastle, 1998, p22.

${ }^{26}$ Governor King's papers in HRNSW, Vol VI: King and Bligh 1806, 1807, 1808, Charles Potter, Sydney, 1898, p9.

${ }_{27}$ The Federal Directory of Newcastle and District, for 1901: comprising street, commercial, trade and professional lists, local, governmental, parliamentary and miscellaneous information, Facsimile edition, Davies \& Cannington, Cardiff (NSW), 1981 \& Lt John Shortland, 'An Eye Sketch of Hunter's River', Hydrographic Department, Ministry of Defence, Taunton Somerset, U.K A6472 Two photographic copies of a plan dated 1797. http://www.newcastle.edu.au/service/archives/chrp/shortland.html (3 September 2006)

${ }^{28}$ See, for example, Tom Griffiths, 'Past Silences: Aborigines and convicts in our history-making', in P. Russell and R. White (eds), Pastiche 1: Reflections on nineteenth-century Australia, Allen \& Unwin, Sydney, 1994, especially pp17-19.

${ }^{29}$ W.J. Goold cited in Nancy Cushing, 'Writing Local History in the Hunter Region: Trends in the Writing of Hunter History', in Cynthia Hunter (ed), Riverchange: Six new histories of the Hunter, Newcastle Region Library, Newcastle, 1998, p4.

${ }^{30}$ Newcastle Morning Herald, 29 January, 1885.

${ }^{31}$ Griffiths, 'Past Silences', p18.

${ }^{32}$ Collins, An Account, p418.

${ }^{33}$ For an overview see John Maynard, 'Muloobinbah (Newcastle) an Aboriginal industrial presence: past and present', Journal of the Royal Australian Historical Society, vol 87, no 2, December, 2001, pp248-66. See also David Andrew Roberts, 'Aborigines, Commandants and Convicts: The Newcastle Penal Settlement', Awaba: $A$ Database of historical materials relating to Aborigines in the Newcastle and Lake Macquarie Regions, http://www.newcastle.edu.au/centre/awaba/awaba/group/amrhd/awaba/history/convicts.html

(7 August 2007)

${ }^{34}$ Newcastle Morning Herald, 8 July, 1897, editorial.

${ }^{35}$ Newcastle Morning Herald, 17 September, 1897.

${ }^{36}$ Maya V. Tucker, 'Centennial Celebrations, 1888' in Australia 1888, Bulletin no 7, April, 1981, p17.

37 Tony Hughes-d'Aeth, Paper Nation: The Story of the Picturesque Atlas of Australasia 1886-1888, Melbourne University Press, Carlton, 2001, p87. 
${ }^{38}$ See, for example, Bain Attwood, 'Introduction: The future as past: Aborigines, Australia and the (dis)course of History', in Bain Attwood (ed), Age of Mabo: History, Aborigines and Australia, Allen \& Unwin, St Leonards, 1996, pXI \& Stuart Macintyre, 'The Writing of Australian History' in D. Borchardt \& V. Crittenden. (eds), Australians: A Guide to the Sources, Fairfax, Syme \&Weldon, Sydney, 1988, pp5-7.

${ }^{39}$ Paul Ashton, Waving the Waratah: Bicentenary New South Wales, New South Wales Bicentennial Council Sydney, 1989, pp20-27 and Julian Thomas, '1938: Past and Present in an Elaborate Anniversary', Australian Historical Studies, (Special issue Making the Bicentenary) vol 23, no 91, October 1988, pp77-89.

${ }^{40}$ Newcastle Morning Herald, 6 September 1947.

${ }^{41}$ Julian Thomas, '1938: Past and Present in an Elaborate Anniversary', Australian Historical Studies, (Special issue Making the Bicentenary) vol 23, no 91, October 1988, pp80-81.

${ }^{42}$ Newcastle Morning Herald, 6, 8, 9 and 20 September, 1947.

${ }^{43}$ Newcastle 150 years: 1797-1947, Newcastle City Council, Newcastle, 1947. See also its successor, Symphony on a City: The story of the city of Newcastle, New South Wales, its birth, its development, and its place in Australia, Published for the Council of the City of Newcastle by Oswald Ziegler Publications, Sydney, c1957.

${ }^{44}$ For an image of a 150 th Anniversary stamp see

http://naa12.naa.gov.au/scripts/PhotoSearchltemDetail.asp?M=0\&B=7534569

45 John Windross and J.P. Ralston, Historical Records of Newcastle: 1797-1897, Federal Printing and Bookbinding Works, Newcastle, 1897 and H.W.H. Huntington, Newcastle Morning Herald, July 1897 to August 1898.

${ }^{46}$ Mal Kearney and Mike Dawson, The Longest Party: A book commemorating Newcastle and the Hunter Region's celebrations in 1988 of Australia's bicentenary of European settlement, Tamerline Publishing, Woodville (NSW), 1989, p13.

${ }^{47}$ Newcastle Morning Herald, 15 September 1988.

${ }^{48}$ This paragraph is based on a reading of 'Australian Bicentenary celebrations in Newcastle and the Hunter Region, photographs and paper cuttings', compiled by Newcastle Region Public Library. An indication of Henry's approach as a historian can be found in Margaret Henry, 'The Battle for Newcastle: Heritage and the Earthquake', in J. Rickard and P. Spearritt (eds), Packaging the Past? Public Histories, Melbourne University Press, Melbourne, 1991, pp102-116. Henry later left Labor becoming a long-serving Independent and then Greens Councillor.

49 John Allen, Bicentenary 88, vol 7, no 4, December 1987, p25.

50 See Bicentenary News: The Newsletter of the Bicentenary Events Corporation, no 1 (February 1997) to no 14 (August 1997), Newcastle Regional Library.

51 See Nancy Cushing, 'Coalopolis to Steel City: Perceptions of Newcastle, 1797 to 1857', Journal of Australian Studies, vol 57, 1998, pp68-9.

${ }^{52}$ Cynthia Hunter (ed), Riverchange: Six New Histories of the Hunter, Newcastle Region Library, Newcastle, 1998.

${ }^{53}$ Newcastle City Council, Newcastle '200 Programme', Copy in the author's possession.

${ }^{54}$ Susan Marsden, Newcastle - A Brief History, Newcastle City Council, Newcastle, 2004. See my review of this book in History Australia, vol 2, no 2, 2005, p57.

${ }^{55}$ Hon Ms Lee Rhiannon, NSW Legislative Council, Parliamentary Debates, 17 March 2004, p7410.

${ }^{56}$ One major concern was the demolition of the Newcastle BHP steel works site, one of the most important industrial heritage sites in regional Australia. For the National Trust's view on this issue see Keith Parsons, 'Trust action: BHP Port Waratah site to be razed: a tragic loss to Australia's steelmaking history', Reflections, National Trust of Australia, New South Wales, Feb-Apr 2003, pp6-7.

57 The full listing can be found at http://www.heritage.nsw.gov.au/07 subnav 01 2.cfm?itemid=5053900 (11 July 2006).

${ }^{58}$ Nancy Cushing, 'The Changing Meaning of Heritage', pp14-16.

${ }^{59}$ Nobbys Coal River Historic Precinct Workshop: Prelude to a Master Plan, April, 2003.

${ }^{60}$ For more on the formation, membership and activities of the Coal River Working Party see www.newcastle.edu.au/coalriver (2 February 2007).

61 Roberts, 'Aborigines, Commandants and Convicts'.

62 The 'Sharing history' concept is succinctly outlined by lan D. Clark in 'Sharing History: A sense for all Australians of a shared ownership of their history', Council for Aboriginal Reconciliation, Key Issue Paper no 4, Australian Government Publishing Service, Canberra, 1994. In hindsight the approach adopted for the Open Day fits into the sharing histories model which, as Kate Darian-Smith notes, can help 'build mutual respect and a sense of commonality.' See Kate Darian-Smith 'Introduction: Challenging Histories, re-reading the past',

Australian Historical Studies Special issue (Challenging Histories), vol 33, no 118, 2002, p2.

${ }^{63}$ Newcastle Herald, 30 and 31 March 2004. 